\title{
Variation in dry grassland communities along a heavy metals gradient
}

\author{
Marcin W. Woch ${ }^{1} \cdot$ Pawel Kapusta $^{2}$ - Anna M. Stefanowicz ${ }^{2}$
}

Accepted: 9 October 2015/Published online: 22 October 2015

(C) The Author(s) 2015. This article is published with open access at Springerlink.com

\begin{abstract}
The aim of this study was to investigate the variation in plant communities growing on metal-enriched sites created by historical $\mathrm{Zn}-\mathrm{Pb}$ mining. The study sites were 65 small heaps of waste rock covered by grassland vegetation and scattered mostly over agricultural land of southern Poland. The sites were described in terms of plant coverage, species richness and composition, and the composition of plant traits. They were classified using phytosociological methods and detrended correspondence analysis. Identified plant communities were compared for vegetation parameters and habitat properties (soil characteristics, distance from the forest) by analysis of variance. The variation in plant community parameters was explained by multiple regression, in which the predictors were properties of the habitat selected on the basis of factor analysis. Grasslands that developed at low and high concentrations of heavy metals in soil were similar to some extent: they were composed on average of 17-20 species (per $4 \mathrm{~m}^{2}$ ), and their total coverage exceeded $90 \%$. The species composition changed substantially with increasing contamination with heavy metals; metal-sensitive species withdrew, while the metal-tolerant became more abundant. Other important predictors of community structure were:
\end{abstract}

Marcin W. Woch

jurania@up.krakow.pl

Paweł Kapusta

p.kapusta@botany.pl

Anna M. Stefanowicz

a.stefanowicz@botany.pl

1 Institute of Biology, Pedagogical University of Kraków, Podchorążych 2, 31-054 Kraków, Poland

2 W. Szafer Institute of Botany, Polish Academy of Sciences, Lubicz 46, 31-512 Kraków, Poland proximity to the forest (responsible for the encroachment of competitive forest species and ruderals), and the thickness of the surface soil (shallow soil favored the formation of the heavy metal grassland). The heavy metal grassland was closely related to the dry calcareous grasslands. The former was an earlier succession stage of the latter at low contamination with heavy metals.

Keywords Historical mining · Heavy metal - Dry grassland $\cdot$ Species richness $\cdot$ Species composition

\section{Introduction}

Heavy metals present in the soil at elevated concentrations can be the overriding factor of the plant species distribution. Numerous studies on the vegetation of metalliferous sites showed that plant species richness and composition changed dramatically under the influence of soil contamination with arsenic, cadmium, chromium, copper, lead, mercury, nickel or zinc (e.g. Simon 1978; Clark and Clark 1981; Lejeune et al. 1996; Brown 2001; Proctor 2003; Strandberg et al. 2006; Becker and Brändel 2007; Válega et al. 2008; Myking et al. 2009; Lucassen et al. 2010; Mapaure et al. 2011; Pandey et al. 2015). Since heavy metals are persistent contaminants, they affect the structure of plant communities not only on a short time scale, through the elimination of stress-sensitive species, but also in the long term, by exerting a strong selective pressure on local populations leading to the emergence of new metaltolerant ecotypes/varieties (Prasad and Hagemeyer 1999; Ernst 2006; Baker et al. 2010).

The most conspicuous effect of microevolution induced by heavy metals is endemic metallophytes. They are obligate metallophytes, i.e. they have developed various 
adaptations to cope with metal toxicity and are restricted to metal-enriched habitats (Kruckeberg and Kruckeberg 1989; Prasad and Hagemeyer 1999). Currently, a high rate of population decline of these species is recorded, which provokes actions towards their conservation (Whiting et al. 2004; Baker et al. 2010; Baumbach 2012). Other metallophytes are more cosmopolitan (facultative metallophytes). They are derived from common species and, owing to their great genetic and phenotypic plasticity, can colonize both metalliferous and non-metalliferous soils (Ernst 2006).

The residual nature, extreme fragmentation and dispersion, and a great geochemical diversity of metal-enriched habitats as well as floristic peculiarity of some (the occurrence of very rare endemics) make it difficult to perform large-scale studies that could improve our understanding of the European heavy metal grassland. Studies concerning the relationship between the concentration of heavy metals in soil and plant species distribution are usually based on a fairly dense sampling of single and relatively small areas (Simon 1978; Brown 1994; Strandberg et al. 2006; Becker and Brändel 2007; Grodzińska and Szarek-Łukaszewska 2009). The effect of heavy metals on vegetation can be difficult to assess in these types of works, because it is often partly related to other soil characteristics, such as $\mathrm{pH}, \mathrm{Ca}$ concentration, or thickness of organic layer (Simon 1978; Brown 1994; Becker and Brändel 2007). Moreover, strong connections (short distances) between the surveyed vegetation patches may significantly bias data by spatial autocorrelation-the structure of a plant community recorded in a given patch may result not only from the local environmental conditions but also community processes occurring in neighboring patches, such as plant dispersal or contagion (Dormann et al. 2007). This complicates statistical analysis and interpretation of the results.

To understand what happens in grassland communities with increasing concentrations of heavy metals in soil, one could establish many sites in a wide gradient of metal contamination (other habitat parameters should not vary to avoid interactions), and the sites should be separated by appropriate distances (to meet the assumption of independence). Such ideal conditions rarely occur in the field. However, we managed to find them in the industrial part of western Małopolska (S. Poland). This region is known for its rich $\mathrm{Zn}-\mathrm{Pb}$ ore deposits, which have been mined since the Middle Ages (Stefanowicz et al. 2014). In our recent study (Stefanowicz et al. 2014), we surveyed nearly $750 \mathrm{~km}^{2}$ of the region searching for the remnants of historical $\mathrm{Zn}-\mathrm{Pb}$ mining. We focused on small heaps of calcareous gangue (waste material) left at the old open pits and shafts. These heaps are termed locally warpie. Many of these sites were afforested. Fortunately, some survived relatively intact on agricultural land, and now they are covered by dry grassland vegetation. They all are metalliferous sites, because the concentrations of heavy metals in the soil are elevated compared to environmental standards. These concentrations vary considerably. According to our measurements, the levels of particular heavy metals ranged as follows: 5-522 $\mathrm{mg} \mathrm{Cd} \mathrm{kg}^{-1}, 0.1-23 \mathrm{~g} \mathrm{~Pb} \mathrm{~kg}^{-1}, 6-51$ $\mathrm{mg} \mathrm{Tl} \mathrm{kg}{ }^{-1}$, and $0.4-70 \mathrm{~g} \mathrm{Zn} \mathrm{kg}^{-1}$ (Stefanowicz et al. 2014). Large fluctuations in metal contamination between sites likely result from the different ore concentration or function of a given shaft (exploitation, exploration, ventilation). Interestingly, metal pollution is the only steep environmental gradient present there-other soil parameters, such as texture, $\mathrm{pH}$, organic matter or nutrient concentration do not vary significantly, which is probably caused by the same history of origin and bedrock material. Distances between neighboring sites can be large (several $\mathrm{km}$ ) or small (a few hundred meters). However, even in the latter case, they form isolated islands in the landscape in terms of both geology and vegetation. Thus, they can be considered as independent samples.

The present study used 65 of these sites to answer several questions concerning the formation of heavy metal grassland, namely: (1) in what range of the soil concentrations of $\mathrm{Cd}, \mathrm{Pb}$ and $\mathrm{Zn}$ does this grassland develop; (2) what are the most important differences between the metaltolerant and metal-sensitive grasslands in terms of species richness and composition; and (3) to what extent does the grassland vegetation respond to variation in other parameters of the habitat?

\section{Materials and methods}

\section{Study area}

Study sites, 65 metal-rich mining waste heaps covered by grassland vegetation (Stefanowicz et al. 2014), were located in western Małopolska (S Poland), between the towns of Olkusz, Krzeszowice, Libiąż and Jaworzno (Fig. 1). In this area, the main geological formations are carbonate rocks of the Triassic and Jurassic period, partially covered by Pleistocene fluvioglacial sands (Cabała et al. 2008). The climate is transitional between temperate oceanic in the west and temperate continental in the east. The average annual air temperature fluctuates between 7.1 and $8.1{ }^{\circ} \mathrm{C}$, and the range of the average annual rainfall is $700-873 \mathrm{~mm}$. The growing season spans between 205 and 215 days (Lorenc 2005). A large part of the area (45\%) is covered by forest. Artificially introduced pine monocultures dominate; impoverished beech forest as well as riparian deciduous forest also occur but are less common. Other types of vegetation include segetal and ruderal 


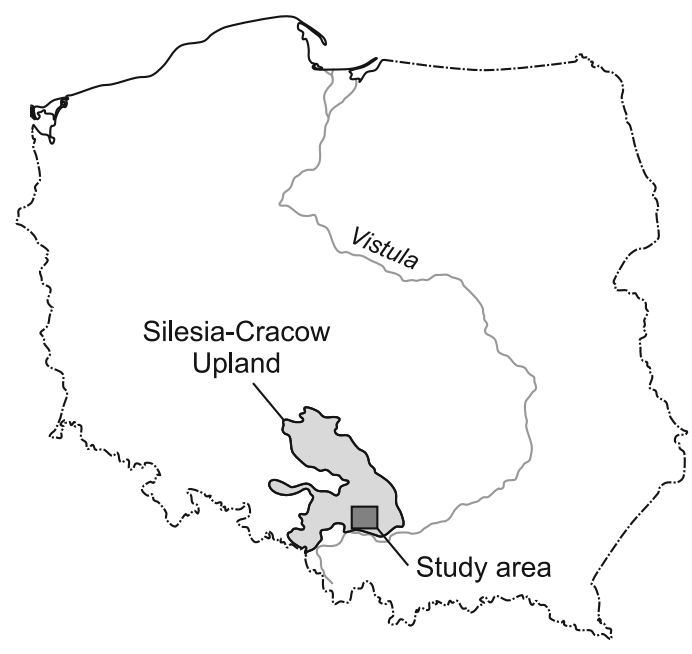

Fig. 1 Location of study area in Poland and 65 study sites. Sites were marked with different symbols according to the type of grassland: the typical variant of Carlino acaulis-Brometum erecti $(C B)$, the Festuca

communities, meadows, wetlands, warm border grasslands and psammophilous grasslands (Tokarska-Guzik 1999; Cohn et al. 2001; Suder and Cabała 2004; Woch 2011; Woch et al. 2013).

\section{Fieldwork}

Vegetation was sampled during the 2012 and 2013 growing seasons, from April to October, on 4- $\mathrm{m}^{2}$ circular plots. Plots were established on the southern, south-eastern or south-western slopes of heaps (one study plot per heap) in homogenous patches of grassland. The cover of vascular plant species for each plot was estimated on a five-degree Braun-Blanquet scale (1964). This measurement was based on at least two visits per plot in each year to ensure that all species had been recorded. Although all heaps were situated in the open area, some of them were near the forest and the influence of woody vegetation (e.g. shadowing) could not be excluded. Therefore, the distance to the nearest forest patch (at least 0.1 ha in size) was measured for each plot directly in the field or by using aerial photographs. In July, three topsoil samples were taken from each heap to a depth of $15 \mathrm{~cm}$ (or less, if the surface soil horizon was shallow) and bulked into one composite sample. The three sampling spots were at the edge of the study plots so as not to disturb plot vegetation. For these sampling spots, the thickness of the organic matter horizon (O horizon) and the surface soil horizon (A or transitional AC horizon) was measured in the field, according to Mocek et al. (2004), and averaged per plot. All heaps were positioned using GPS.

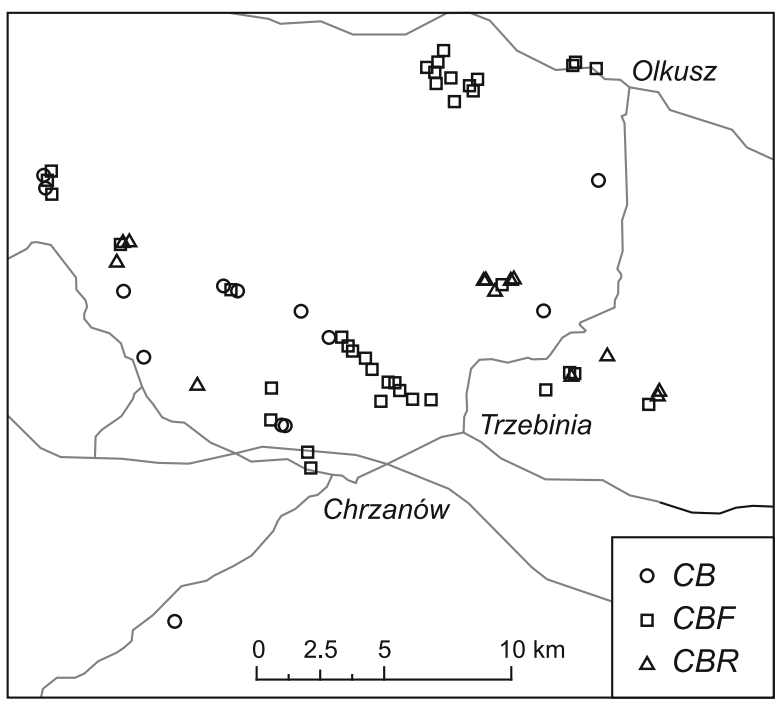

ovina variant $(C B F)$ and the Rubus caesius variant $(C B R)$. Major cities and main roads are also indicated

\section{Vegetation data handling}

Plant nomenclature followed Mirek et al. (2002). Plant communities were identified according to Chytrý (2007). For each plot, species richness (total number of plant species) and the number of species representing different types of seed dispersal (Podbielkowski 1995), Grime's CSR strategies (Grime 2001), functional groups (Rutkowski 2008), life forms (Raunkiaer 1934), and vegetation classes (Chytrý 2007, 2009, 2013) were calculated.

\section{Soil analysis}

Prior to the analysis, soil samples were sieved $(2 \mathrm{~mm}$ mesh) and dried at $105{ }^{\circ} \mathrm{C}$. The content of sand, silt and clay was determined by a combination of sieving and sedimentation, and the soil $\mathrm{pH}$ was tested with a $\mathrm{pH}$-meter after extraction with water in a 1:5 (w:v) ratio. Organic carbon was assessed using the dry combustion technique with a Leco RC-612. Total sulfur was measured with a Leco SC-144 DR. Total nitrogen was determined using the Kjeldahl method. The soil was digested in $\mathrm{H}_{2} \mathrm{SO}_{4}$ with Kjeltabs $\left(\mathrm{K}_{2} \mathrm{SO}_{4}+\mathrm{CuSO}_{4} \cdot 5 \mathrm{H}_{2} \mathrm{O}\right.$; Foss Tecator Digestor Auto) followed by distillation in a Foss Tecator Kjeltec 2300 Analyser Unit. To determine the concentration of pseudo-total (hereafter referred to as "total") and EDTA metals, two soil extraction methods were applied: hot concentrated $\mathrm{HClO}_{4}$ (Foss Tecator Digestor Auto; $\mathrm{Ca}, \mathrm{Cd}$, $\mathrm{K}, \mathrm{Mg}, \mathrm{Pb}, \mathrm{Tl}, \mathrm{Zn})$ and $0.05 \mathrm{M}$ EDTA (Cd, $\mathrm{Pb}, \mathrm{Tl}, \mathrm{Zn})$. The metal concentrations in soil extracts were analyzed by flame atomic absorption spectrometry (Varian 220 FS). The total phosphorus was measured using the molybdenum 
blue method with a colorimeter (Hach-Lange DR 3800) after digestion in hot $\mathrm{HClO}_{4}$. Available (Olsen) phosphorus was measured with an ion chromatograph (Dionex ICS1100) following the extraction of soil with $0.5 \mathrm{M} \mathrm{NaHCO}_{3}$, $\mathrm{pH}$ 8.5.

\section{Data analysis}

Prior to statistical analyses, the variables (properties of habitat and vegetation parameters) were transformed with a logarithmic or exponential function, according to the formulas proposed by Økland et al. (2001), and expressed on a $0-1$ scale in order to achieve homogeneity of variances (Økland 2007). Detrended correspondence analysis (DCA) was applied for the plant data to identify important ecological gradients determining plant species distribution and to verify the classification of the plots performed with phytosociological methods. One-way ANOVA (or Kruskal-Wallis test, in case of violation of the assumptions of normality and homogeneity of variance) was used to compare habitat properties and vegetation parameters between plant community groups identified by the phytosociological analysis. Factor analysis with a varimax rotation was performed to reveal interrelationships between soil variables and obtain a small number of uncorrelated factors representing the main sources of variation in the soil dataset. One variable ( $\mathrm{O}$ horizon thickness) was excluded from this analysis due to its distribution, which could not be normalized. The number of factors was established on the basis of Kaiser's criterion (eigenvalue $>1$ ). Factors were used together with the distance from the forest (DFF) in multiple regression (with forward stepwise selection procedure) as independent representatives of habitat conditions to explain plant species richness and composition (scores for axes 1 and 2 in DCA). Analyses were carried out using STATISTICA 9 (StatSoft Inc. Tulsa, OK, USA) and CANOCO 4.5 software (ter Braak and Šmilauer 2002).

\section{Results}

\section{Grassland vegetation of old mining heaps}

Plant communities included in this study were dry calcareous grasslands of the Carlino acaulis-Brometum erecti association (the Bromion erecti alliance, the FestucoBrometea class). They occurred in three variants: (1) closed grassland dominated by Brachypodium pinnatum (typical variant, $C B)$, (2) loose heavy metal grassland with Festuca ovina as the main component (the Festuca ovina variant, $C B F$ ), and (3) grassland with woody and ruderal plants (the Rubus caesius variant, $C B R$ ).
Vegetation typical of Carlino acaulis-Brometum erecti $(C B)$ was found on 13 heaps. It was strongly dominated by Brachypodium pinnatum. Other frequent components of the $C B$ community were Euphorbia cyparissias, Lotus corniculatus, Achillea collina, Galium album, Medicago falcata and Peucedanum oreoselinum. The $C B$ plots were almost entirely covered with vegetation and contained an average of nearly 20 species, most of which belonged to the Festuco-Brometea class (Table 1). This community was distinguished by a higher than elsewhere number of zoochorous plants and stress-tolerant competitive plants.

The $C B F$ variant was most abundant in this study $(\mathrm{N}=38)$. Its most dominant species was the metal-tolerant grass, Festuca ovina. The $C B F$ plots were overgrown mainly by xerophilous plants, such as Euphorbia cyparissias, Potentilla arenaria, Thymus pulegioides and Scabiosa ochroleuca. They had on average a similar number of species as the $C B$ plots, but were more open in terms of vegetation cover (Table 1). The Festuco-Brometea plants were dominant, but contrary to the $C B$ variant, they were accompanied by plants of many other vegetation classes. The $C B F$ variant was also characterized by the highest number of anemochorous plants, forbs and chamaephytes as well as sporadic but statistically significant presence of stress-tolerators (Table 1). The members of this community were facultative metallophytes, such as Asperula cynanchica, Cardaminopsis halleri, Dianthus carthusianorum, Gypsophila fastigiata and Silene vulgaris, which were often absent in other types of grasslands.

The $C B R$ variant occupied 14 heaps. This grassland had fully closed vegetation (Table 1). It contained an average of 17 species, among which the most frequent were Rubus caesius, Festuca rubra and Galium album. An important role in this community was played by synanthropic species of wide ecological amplitude from the classes of Artemisietea vulgaris and Epilobietea angustifolii, e.g. Calamagrostis epigejos, Pteridium aquilinum or Solidago canadensis. Some sites were dominated by one or two of these species. In comparison to the two other grassland types, the $C B R$ variant had the lowest number of the Festuco-Brometea plants, anemochorous plants and forbs, while the number of competitors such as woody plants was the highest (Table 1). Another feature of this community was the presence of forest species from the Carpino-Fagetea class, including Melica nutans.

The three variants occupied distinctly different but not isolated positions along the ecological gradients defined by DCA axes (Fig. 2). The $C B F$ grasslands were shifted to the left in relation to the $C B$ and $C B R$ grasslands. The latter two were vertically spaced apart, as $C B$ took the upper, and $C B R$ the lower side of the DCA diagram. The first and second axis explained $13.4 \%$ (eigenvalue $=0.39$ ) and 
Table 1 Plant community characteristics averaged (mean \pm standard deviation) for the three types of vegetation (expressed as number of species with the exception of cover)

\begin{tabular}{|c|c|c|c|}
\hline Variable & $\begin{array}{l}C B \\
(\mathrm{~N}=13)\end{array}$ & $\begin{array}{l}C B F \\
(\mathrm{~N}=38)\end{array}$ & $\begin{array}{l}C B R \\
(\mathrm{~N}=14)\end{array}$ \\
\hline Cover $(\%)^{*}$ & $96.5 \pm 5.9^{\mathrm{ab}}$ & $90.5 \pm 11.5^{\mathrm{a}}$ & $98.2 \pm 5.4^{\mathrm{b}}$ \\
\hline Species richness & $19.6 \pm 5.6$ & $20.3 \pm 6.0$ & $16.9 \pm 4.8$ \\
\hline Forb & $12.3 \pm 4.0^{\mathrm{ab}}$ & $13.6 \pm 4.2^{\mathrm{a}}$ & $9.9 \pm 3.5^{\mathrm{b}}$ \\
\hline Grass & $4.1 \pm 1.4$ & $4.0 \pm 1.9$ & $3.9 \pm 1.7$ \\
\hline Legume & $2.7 \pm 0.9$ & $2.1 \pm 1.2$ & $1.9 \pm 0.9$ \\
\hline Woody plant* & $0.5 \pm 0.5^{\mathrm{ab}}$ & $0.5 \pm 0.8^{\mathrm{a}}$ & $1.3 \pm 1.1^{\mathrm{b}}$ \\
\hline $\mathrm{C}$ (competitor) & $3.9 \pm 2.0^{\mathrm{a}}$ & $4.3 \pm 1.9^{\mathrm{a}}$ & $7.5 \pm 2.3^{\mathrm{b}}$ \\
\hline CR (competitive ruderal)* & $0.5 \pm 0.7$ & $0.8 \pm 0.9$ & $0.6 \pm 0.8$ \\
\hline CSR (mixed strategy) & $9.7 \pm 4.4^{\mathrm{a}}$ & $10.7 \pm 3.8^{\mathrm{a}}$ & $5.6 \pm 3.4^{\mathrm{b}}$ \\
\hline $\mathrm{R}$ (ruderal)* & $0.2 \pm 0.6$ & $0.1 \pm 0.2$ & $0.1 \pm 0.3$ \\
\hline $\mathrm{S}$ (stress tolerator)* & $0.3 \pm 0.5^{\mathrm{ab}}$ & $0.8 \pm 0.6^{\mathrm{a}}$ & $0.1 \pm 0.5^{\mathrm{b}}$ \\
\hline SC (stress-tolerant competitor) & $4.8 \pm 1.3^{\mathrm{a}}$ & $3.3 \pm 1.9^{\mathrm{ab}}$ & $3.0 \pm 1.5^{\mathrm{b}}$ \\
\hline SR (stress-tolerant ruderal)* & $0.2 \pm 0.4$ & $0.2 \pm 0.5$ & $0.0 \pm 0.0$ \\
\hline Chamaephyte & $1.5 \pm 1.3^{\mathrm{a}}$ & $3.1 \pm 1.1^{\mathrm{b}}$ & $1.3 \pm 1.3^{\mathrm{a}}$ \\
\hline Geophyte & $2.5 \pm 1.0$ & $3.0 \pm 1.2$ & $3.3 \pm 1.7$ \\
\hline Hemicryptophyte & $16.6 \pm 4.4$ & $16.1 \pm 5.2$ & $12.6 \pm 4.1$ \\
\hline Liana* & $0.1 \pm 0.3$ & $0.0 \pm 0.0$ & $0.1 \pm 0.3$ \\
\hline Phanerophyte* & $0.7 \pm 0.8$ & $0.7 \pm 0.9$ & $1.4 \pm 1.2$ \\
\hline Terophyte* & $0.7 \pm 0.9$ & $0.5 \pm 0.7$ & $0.5 \pm 0.5$ \\
\hline Anemochory & $14.2 \pm 4.3^{\mathrm{ab}}$ & $15.2 \pm 4.3^{\mathrm{a}}$ & $11.7 \pm 2.9^{\mathrm{b}}$ \\
\hline Antropochory* & $0.5 \pm 0.8$ & $0.6 \pm 0.6$ & $0.9 \pm 0.9$ \\
\hline Autochory & $2.6 \pm 0.8$ & $2.4 \pm 1.5$ & $1.9 \pm 1.1$ \\
\hline Hydrochory* & $0.5 \pm 0.5$ & $0.1 \pm 0.3$ & $0.2 \pm 0.4$ \\
\hline Myrmecochory* & $3.4 \pm 1.6$ & $3.0 \pm 1.7$ & $2.5 \pm 2.3$ \\
\hline Zoochory & $3.8 \pm 2.1^{\mathrm{a}}$ & $2.0 \pm 1.7^{\mathrm{b}}$ & $3.2 \pm 1.6^{\mathrm{ab}}$ \\
\hline Artemisietea vulgaris & $0 \pm 0^{\mathrm{a}}$ & $0.2 \pm 0.4^{\mathrm{a}}$ & $1.9 \pm 1^{\mathrm{b}}$ \\
\hline Asplenietea trichomanis & $0 \pm 0^{\mathrm{a}}$ & $0.6 \pm 0.5^{\mathrm{b}}$ & $0.1 \pm 0.4^{\mathrm{a}}$ \\
\hline Calluno-Ulicetea* & $0.2 \pm 0.4$ & $0.4 \pm 0.7$ & $0.1 \pm 0.3$ \\
\hline Carpino-Fagetea & $0.4 \pm 0.5^{\mathrm{ab}}$ & $0.1 \pm 0.3^{\mathrm{a}}$ & $0.6 \pm 0.5^{\mathrm{b}}$ \\
\hline Epilobietea angustifolii & $0 \pm 0^{\mathrm{a}}$ & $0.1 \pm 0.3^{\mathrm{a}}$ & $0.8 \pm 0.6^{\mathrm{b}}$ \\
\hline Festuco-Brometea & $12.9 \pm 3.8^{\mathrm{a}}$ & $11.4 \pm 4.4^{\mathrm{a}}$ & $7.6 \pm 3.4^{\mathrm{b}}$ \\
\hline Koelerio glaucae-Corynephoretea canescentis & $0.5 \pm 0.7^{\mathrm{a}}$ & $1.2 \pm 0.7^{\mathrm{b}}$ & $0.1 \pm 0.4^{\mathrm{a}}$ \\
\hline Molinio-Arrhenatheretea* & $4.5 \pm 2.4$ & $5.5 \pm 2$ & $4 \pm 1.7$ \\
\hline Quercetea robori-petraeae & $0 \pm 0^{\mathrm{a}}$ & $0.1 \pm 0.3^{\mathrm{a}}$ & $0.6 \pm 0.5^{\mathrm{b}}$ \\
\hline
\end{tabular}

$C B$ typical variant of Carlino acaulis-Brometum erecti, $C B F$ the Festuca ovina variant, $C B R$ the Rubus caesius variant. Statistically significant $(P<0.05)$ differences between the groups were detected using oneway ANOVA, followed by Tukey's test or the Kruskal-Wallis test, followed by Dunn's test (variables analyzed with a non-parametric test were asterisked). Means labelled with different letters are statistically different
$7.3 \%$ (eigenvalue $=0.22$ ) of the variation in the species composition, respectively.

\section{Variability of old mining heap habitats}

There were significant differences observed between the heaps overgrown by the three grassland communities (Table 2). The $C B F$ heaps had large amounts of $\mathrm{Cd}, \mathrm{Pb}$ and $\mathrm{Zn}$ in soil (both total and EDTA-extractable), while the $C B$ and $C B R$ heaps were only slightly or moderately contaminated with these metals. The latter two differed in the distance from the forest (DFF): $C B$ heaps were situated quite far from the forest, while $C B R$ heaps almost always bordered on forest. $C B F$ heaps were intermediate in this respect. Other considerable differences were found for the total concentration of $S$ (the highest on the $C B F$ plots) and available $\mathrm{P}$ (the highest on the $C B R$ plots). 


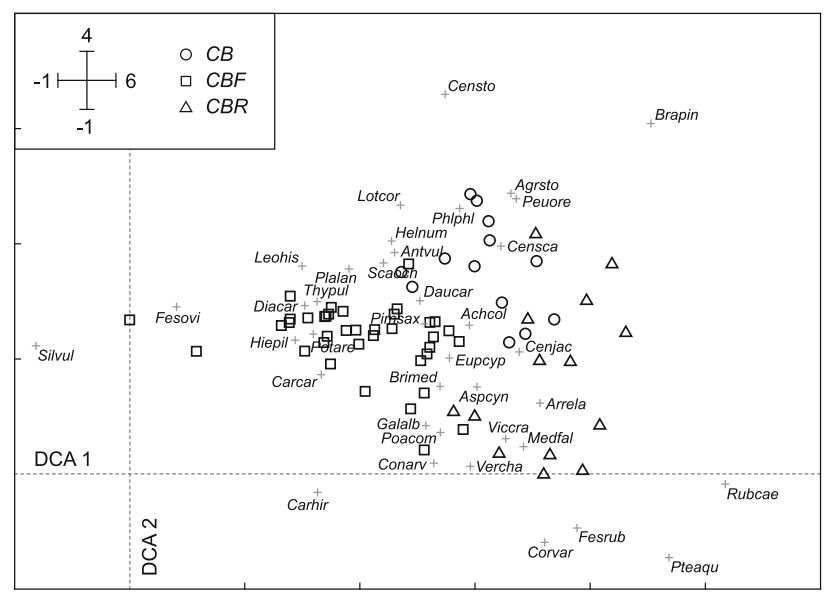

Fig. 2 DCA ordination diagram of 65 vegetation samples. Different symbols indicate the three types of grassland: the typical variant of Carlino acaulis-Brometum erecti $(C B)$, the Festuca ovina variant $(C B F)$ and the Rubus caesius variant $(C B R)$. Species, which occurred infrequently (arbitrarily, $<10 \%$ of sites) were not included in this analysis. Diagram shows only important differential species (weight higher than $10 \%$ ): Achillea collina (Achcol), Agrostis stolonifera (Agrsto), Anthyllis vulneraria (Antvul), Arrhenatherum elatius (Arrela), Asperula cynanchica (Aspcyn), Brachypodium pinnatum (Brapin), Briza media (Brimed), Carex caryophyllea (Carcar), Carex hirta (Carhir), Centaurea jacea (Cenjac), Centaurea scabiosa (Censca), Centaurea stoebe (Censto), Convolvulus arvensis (Conarv), Coronilla varia (Corvar), Daucus carota (Daucar), Dianthus carthusianorum (Diacar), Euphorbia cyparissias (Eupcyp), Festuca ovina (Fesovi), Festuca rubra (Fesrub), Galium album (Galalb), Helianthemum nummularium (Helnum), Hieracium pilosella (Hiepil), Leontodon hispidus (Leohis), Lotus corniculatus (Lotcor), Medicago falcata (Medfal), Peucedanum oreoselinum (Peuore), Phleum phleoides (Phlphl), Pimpinella saxifraga (Pimsax), Plantago lanceolata (Plalan), Poa compressa (Poacom), Potentilla arenaria (Potare), Pteridium aquilinum (Pteaqu), Rubus caesius (Rubcae), Scabiosa ochroleuca (Scaoch), Silene vulgaris (Silvul), Thymus pulegioides (Thypul), Veronica chamaedrys (Vercha), Vicia cracca (Viccra)

Although $C B F$ soil was on average more contaminated than others, part of the $C B F$ sites (ca. one third) fell into the common range of low and moderate levels of $\mathrm{Cd}, \mathrm{Pb}$ and $\mathrm{Zn}$ together with $C B$ sites. For example, the concentration of total $\mathrm{Cd}$ in $C B$ soil varied from 6 to $57 \mathrm{mg} \mathrm{kg}^{-1}$. There were $11 C B F$ sites with a similar range of values (Fig. 3). These sites were compared (Student's $t$ test for independent samples) with $C B$ sites to identify the factors other than heavy metal contamination that could be responsible for the development of two variants (typical and metal-tolerant) of grassland communities. The results of these comparisons demonstrated that the thickness of $\mathrm{A} / \mathrm{AC}$ horizon, together with the composition of soil particles, were the only variables explaining the division into the $C B$ and $C B F$ categories; the $C B$ sites had almost two times thicker the $\mathrm{A} / \mathrm{AC}$ horizon $(12 \mathrm{~cm})$, with a slightly higher proportion of sand particles than the $C B F$ sites $(7 \mathrm{~cm})$.

A factor analysis reduced 21 physicochemical properties of the soil to 6 factors explaining $83 \%$ of the variance in the soil data (Table 3). Factor 1 (F1) represented heavy metal contamination, since it grouped concentrations of both total and EDTA-extractable $\mathrm{Cd}, \mathrm{Pb}$ and $\mathrm{Zn}$. Factor 2 (F2) comprised total $\mathrm{Ca}, \mathrm{Tl}$ and $\mathrm{Mg}$, and negatively correlated with these metals, the thickness of A/AC horizon; thus, F2 reflected the amount of weathered calcareous gangue in the sampled soil. Other factors represented organic matter content (F3), soil particle composition (F4 and $\mathrm{F} 5$ ), and $\mathrm{pH}$, which negatively correlated with total $\mathrm{P}$ (F6).

\section{Relationship between habitat properties and vegetation}

DFF and six factors representing soil properties were predictors of plant community parameters in multiple regression. All predictors were largely independent of each other: the factors were orthogonal and they did not correlate significantly with DFF. Table 4 shows the results of the multiple regression analysis.

The properties of the habitat explained $21 \%$ of the variation in species richness, and 69 and $28 \%$ of the variation in species composition represented by DCA 1 and DCA 2 scores, respectively. Heavy metal contamination (represented by F1) was the most important determinant of plant community structure. It slightly reduced the number of species and dramatically altered the vegetation. Simple correlations between total $\mathrm{Cd}, \mathrm{Pb}$ and $\mathrm{Zn}$ and selected plant species (Table 5) showed that increasing heavy metal stress caused the disappearance of metal-sensitive plants (typical of $C B$ ), such as Brachypodium pinnatum, and the emergence of metal-tolerant ones (typical of $C B F$ ), including Carex caryophyllea and Festuca ovina. The amount of carbonate minerals (represented by F2), which was high in shallow soils, had a positive influence on the species richness and affected the species composition (DCA 1) in a similar way as heavy metals. Soil acidity and the associated $\mathrm{P}$ concentration (represented by F6) had a negative effect on species richness, and also significantly determined the species composition (DCA 2). DFF had no effect on the species richness but significantly shaped the species composition (DCA 1 and DCA 2). According to Table 5, this variable was relevant to the few species: Rubus caesius (plant characteristic of ruderal and forest edge habitats) and Lotus corniculatus and Carlina acaulis (plants associated with grassland habitats).

\section{Discussion}

This study showed that the amount of heavy metals $(\mathrm{Cd}, \mathrm{Pb}$ and $\mathrm{Zn}$ ) in the soil of old mining heaps strongly determined the species composition of plant communities growing 
Table 2 Habitat properties averaged (mean \pm standard deviation) for the three vegetation types

\begin{tabular}{|c|c|c|c|}
\hline Variable & $\begin{array}{l}C B \\
(\mathrm{~N}=13)\end{array}$ & $\begin{array}{l}C B F \\
(\mathrm{~N}=38)\end{array}$ & $\begin{array}{l}C B R \\
(\mathrm{~N}=14)\end{array}$ \\
\hline $\mathrm{DFF}(\mathrm{m})$ & $175 \pm 150^{\mathrm{a}}$ & $70 \pm 94^{\mathrm{ab}}$ & $28 \pm 58^{\mathrm{b}}$ \\
\hline O horizon thickness $(\mathrm{cm})^{*}$ & $1.9 \pm 2.5$ & $1.6 \pm 1.9$ & $2.4 \pm 1.9$ \\
\hline $\mathrm{A} / \mathrm{AC}$ horizon thickness $(\mathrm{cm})$ & $11.4 \pm 4.8$ & $7.2 \pm 4.8$ & $12.3 \pm 9.0$ \\
\hline $\mathrm{pH}$ & $8.2 \pm 0.3$ & $8.1 \pm 0.3$ & $7.9 \pm 0.4$ \\
\hline Sand $(\%)$ & $71.2 \pm 8.6$ & $64.3 \pm 10.5$ & $65.4 \pm 10.8$ \\
\hline Silt $(\%)$ & $16.5 \pm 6.0$ & $21.1 \pm 7.9$ & $21.4 \pm 9.3$ \\
\hline Clay $(\%)$ & $12.2 \pm 6.8$ & $14.6 \pm 6.5$ & $13.2 \pm 4.1$ \\
\hline $\mathrm{C}_{\text {ORGANIC }}(\%)$ & $4.39 \pm 1.94$ & $5.50 \pm 3.20$ & $4.69 \pm 2.49$ \\
\hline $\mathrm{N}(\%)$ & $0.322 \pm 0.135$ & $0.327 \pm 0.143$ & $0.316 \pm 0.100$ \\
\hline $\mathrm{S}(\%)$ & $0.080 \pm 0.031^{\mathrm{a}}$ & $0.198 \pm 0.177^{b}$ & $0.076 \pm 0.032^{\circ}$ \\
\hline $\mathrm{P}\left(\mathrm{mg} \mathrm{kg}^{-1}\right)^{*}$ & $641 \pm 214$ & $697 \pm 104$ & $745 \pm 158$ \\
\hline $\mathrm{P}_{\text {OLSEN }}\left(\mathrm{mg} \mathrm{kg}^{-1}\right)$ & $3.24 \pm 2.51^{\mathrm{ab}}$ & $2.53 \pm 1.53^{\mathrm{a}}$ & $4.79 \pm 2.06^{\mathrm{b}}$ \\
\hline $\mathrm{K}\left(\mathrm{g} \mathrm{kg}^{-1}\right)$ & $1.72 \pm 1.58$ & $1.90 \pm 1.18$ & $1.40 \pm 0.72$ \\
\hline $\mathrm{Ca}\left(\mathrm{g} \mathrm{kg}^{-1}\right)^{*}$ & $59.8 \pm 55.7$ & $67.3 \pm 34.0$ & $45.0 \pm 32.6$ \\
\hline $\operatorname{Mg}\left(\mathrm{g} \mathrm{kg}^{-1}\right)$ & $20.2 \pm 19.7$ & $29.2 \pm 16.0$ & $23.3 \pm 19.0$ \\
\hline $\mathrm{Cd}\left(\mathrm{mg} \mathrm{kg}^{-1}\right)^{*}$ & $17 \pm 14^{\mathrm{a}}$ & $127 \pm 107^{b}$ & $18 \pm 9^{\mathrm{a}}$ \\
\hline $\mathrm{Pb}\left(\mathrm{g} \mathrm{kg}^{-1}\right)^{*}$ & $0.58 \pm 0.66^{\mathrm{a}}$ & $4.07 \pm 4.60^{\mathrm{b}}$ & $0.68 \pm 0.38^{\mathrm{a}}$ \\
\hline $\mathrm{Zn}\left(\mathrm{g} \mathrm{kg}^{-1}\right)$ & $2.8 \pm 2.3^{\mathrm{a}}$ & $22.3 \pm 19.1^{\mathrm{b}}$ & $3.3 \pm 2.1^{\mathrm{a}}$ \\
\hline $\mathrm{Tl}\left(\mathrm{mg} \mathrm{kg}^{-1}\right)$ & $14.1 \pm 7.5$ & $20.8 \pm 9.1$ & $13.8 \pm 5.8$ \\
\hline $\mathrm{Cd}_{\text {EDTA }}\left(\mathrm{mg} \mathrm{kg}^{-1}\right)^{*}$ & $7.8 \pm 6.3^{\mathrm{a}}$ & $44.4 \pm 40.8^{\mathrm{b}}$ & $6.8 \pm 3.0^{\mathrm{a}}$ \\
\hline $\operatorname{Pb}_{\text {EDTA }}\left(\mathrm{g} \mathrm{kg}^{-1}\right)^{*}$ & $0.25 \pm 0.21^{\mathrm{a}}$ & $1.31 \pm 1.57^{\mathrm{b}}$ & $0.29 \pm 0.27^{\mathrm{ab}}$ \\
\hline $\mathrm{Zn}_{\text {EDTA }}\left(\mathrm{g} \mathrm{kg}^{-1}\right)^{*}$ & $0.56 \pm 0.97^{\mathrm{a}}$ & $2.58 \pm 2.81^{\mathrm{b}}$ & $0.32 \pm 0.12^{\mathrm{a}}$ \\
\hline $\mathrm{Tl}_{\text {EDTA }}\left(\mathrm{mg} \mathrm{kg}^{-1}\right)$ & $0.96 \pm 0.73$ & $0.96 \pm 0.52$ & $0.74 \pm 0.44$ \\
\hline
\end{tabular}

$C B$ typical variant of Carlino acaulis-Brometum erecti, $C B F$ the Festuca ovina variant, $C B R$ the Rubus caesius variant, $D F F$ distance from the forest. Statistically significant $(P<0.05)$ differences between the groups were detected using one-way ANOVA, followed by Tukey's test or the Kruskal-Wallis test, followed by Dunn's test (variables analyzed with a non-parametric test were asterisked). Means labelled with different letters are statistically different there. As expected, the number of metal-sensitive species decreased, while the number of metal-tolerant increased with increasing heavy metal contamination. As a result, the typical dry calcareous grassland (dominated by Brachypodium pinnatum; $C B$ ) was replaced by its heavy metal variant (dominated by Festuca ovina; $C B F$ ). The vegetation encroaching on heavily contaminated soil $(C B F)$ was mainly composed of common grassland species with a wide ecological amplitude, but of low competitiveness, for example, Carex caryophyllea, Festuca ovina, Silene vulgaris, Thymus pulegioides, Dianthus carthusianorum or Potentilla arenaria. According to the literature (Ernst 2006), such species can produce ecotypes able to colonize metalliferous substrates. Some of them (e.g. Festuca ovina, Silene vulgaris) are regarded as facultative metallophytes, characteristic of Central European heavy metal grasslands (Ernst 1974; Punz and Mucina 1997; Brown 2001; SzarekŁukaszewska and Grodzińska 2011).

Analysis of plant community in terms of life forms and life history strategies can be helpful in understanding the nature of the selection pressure acting on plant populations (Grime 2001). For example, a significant share of stress tolerators, chamaephytes and plants dispersed by wind may be a response to harsh site conditions, which happens in young, disturbed habitats (Grime 2001; Řehounková and Prach 2010). In contrast, the prevalence of competitors, phanerophytes and plants dispersed by animals indicates less extreme situations typical of late-successional stages (Olsson 1987; Grime 2001; Novák and Prach 2003; Rehounková and Prach 2010). Following these guidelines, the $C B F$ habitats can be considered more hostile in comparison with others, especially the $C B R$ habitats. However, these differences are small, which probably reflects the close relationship between the grasslands surveyed.

Multiple regression showed that the total $\mathrm{Ca}$ and $\mathrm{Mg}$ could be relevant predictors of plant species composition. These variables negatively correlated with the thickness of $\mathrm{A} / \mathrm{AC}$ horizon, as indicated by factor analysis, thus it reflected to some extent the development of the soil (the shallower the soil, the more $\mathrm{Ca}$ - and $\mathrm{Mg}$-rich mining waste 

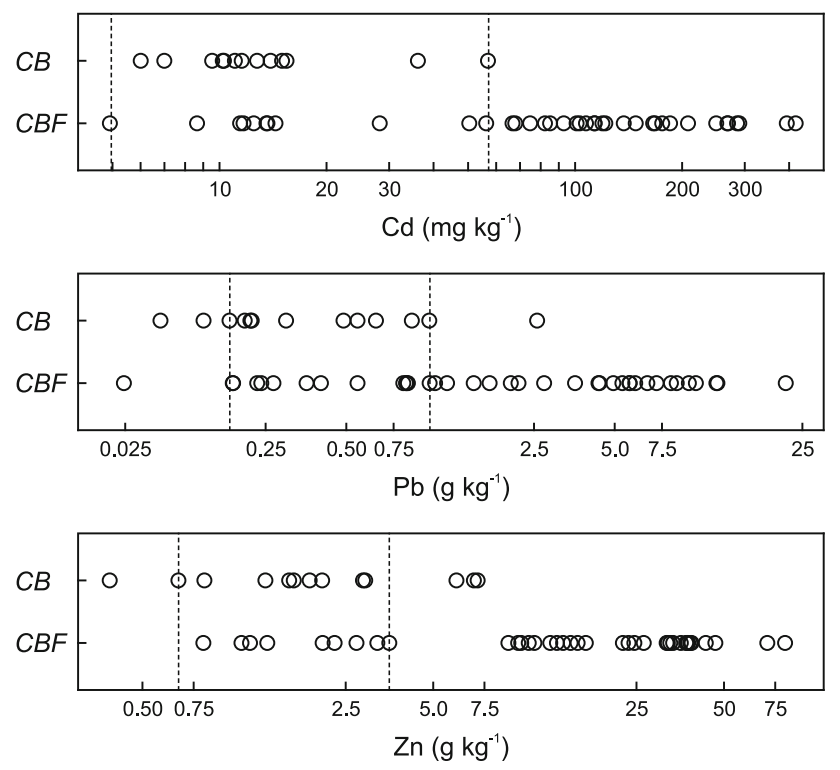

Fig. 3 Raw data for the total concentration of $\mathrm{Cd}, \mathrm{Pb}$ and $\mathrm{Zn}$ in soils under typical vegetation of Carlino acaulis-Brometum erecti $(C B)$ and its Festuca ovina variant $(C B F)$ presented on logarithmic scale. The dashed lines indicate the range of metal concentration, within which $C B$ and $C B F$ sites were compared in terms of natural habitat properties. The ranges were set to obtain homogeneity of variance and insignificant differences in a given metal concentration between the two groups of sites (see the text for explanation)

minerals in soil samples). The importance of this factor in shaping the structure of grassland communities becomes apparent in the analysis of stratified data (excluding the sites with high soil concentrations of $\mathrm{Cd}, \mathrm{Pb}$ and $\mathrm{Zn}$ ). The thickness of A/AC horizon, under low and moderate heavy metal contamination, was the primary determinant of the plant species composition: the $C B F$ grassland developed on shallow, often skeletal soil, while the $C B$ grassland on well-developed soil. This means that the $C B F$ grassland, under certain environmental conditions (lower heavy metal stress), can be succeeded by the $C B$ grassland along with the ongoing process of soil formation.

The distance from the forest (DFF) was another parameter that caused substantial changes in the structure of grassland communities studied. This is in line with many authors (Butaye et al. 2002; Novák and Konvička 2006; Prach and Řehounková 2006; Pen-Mouratov et al. 2014) who found that the pattern of primary succession in manmade island habitats was dependent on the distance from other habitats; these authors concluded that new sites were effectively colonized by vegetation growing no further than a few dozen meters away. In this study, the proximity of the forest triggered a transition from the typical $C B$ community into its $C B R$ variant. This was probably due to increased seed rain of forest species (McDonnell and Stiles 1983; Myster and Pickett 1993), including competitive woody plants. Also, the deposition of tree litter may play an important role in structuring the plant community (note that the mean DFF was $28 \mathrm{~m}$, which means that many $C B R$ sites were adjacent to forest), since it can inhibit the germination of some plants and increase the availability of some nutrients (Loydi et al. 2013). The latter effect was

Table 3 The results of the factor analysis of soil properties (see Table 2 for explanation of variables)

\begin{tabular}{lll}
\hline Factor & $\begin{array}{l}\text { Variance } \\
\text { explained }(\%)\end{array}$ & Variables (with the highest loading values) \\
\hline F1 & 28.9 & $\mathrm{Cd}_{\text {EDTA }}(0.948), \mathrm{Cd}(0.934), \mathrm{Zn}(0.921), \mathrm{Zn}_{\mathrm{EDTA}}(0.916)$, \\
& 13.8 & $\mathrm{~Pb}(0.898), \mathrm{Pb}_{\text {EDTA }}(0.879), \mathrm{S}(0.628), \mathrm{P}_{\text {OLSEN }}(-0.518)$ \\
F2 & 11.6 & $\mathrm{Ca}(0.862), \mathrm{Tl}(0.826), \mathrm{Mg}(0.783), \mathrm{A} / \mathrm{AC}$ horizon thickness $(-0.671)$ \\
F3 & 11.2 & $\mathrm{C}_{\text {ORGANIC }}(0.87), \mathrm{N}(0.789), \mathrm{Tl}$ \\
$\mathrm{EDTA}$ & $(0.705)$ \\
F4 & 9.8 & Silt $(0.923)$, sand $(-0.798)$ \\
F5 & 7.6 & $\mathrm{Clay}(0.912), \mathrm{K}(0.833)$, sand $(-0.509)$ \\
F6 & $\mathrm{pH}(-0.763), \mathrm{P}(0.762)$ \\
\hline
\end{tabular}

Table 4 Effects of the distance from the forest and soil properties (represented by factors; see Table 3) on the plant species richness and composition (DCA 1, DCA 2), illustrated by standardized (Beta) coefficients of multiple regression

\begin{tabular}{|c|c|c|c|c|c|c|c|c|c|c|}
\hline \multirow[t]{2}{*}{ Dependent variable } & \multirow[t]{2}{*}{$\mathrm{N}$} & \multicolumn{2}{|c|}{ Regression summary } & \multicolumn{7}{|c|}{ Beta coefficients } \\
\hline & & $R^{2}$ & $P$ & $\mathrm{DFF}$ & F1 & $\mathrm{F} 2$ & F3 & $\mathrm{F} 4$ & F5 & F6 \\
\hline Species richness & 62 & 0.207 & 0.0040 & 0.15 & $-0.30 *$ & $0.24 *$ & 0.18 & n.i. & 0.20 & $-0.29 *$ \\
\hline DCA1 & 62 & 0.689 & 0.0000 & $-0.19 *$ & $-0.73 * * *$ & $-0.38 * * *$ & 0.08 & 0.14 & -0.09 & 0.12 \\
\hline DCA2 & 61 & 0.281 & 0.0001 & $0.25^{*}$ & n.i. & n.i. & -0.17 & 0.17 & n.i. & $-0.38 * *$ \\
\hline
\end{tabular}

$N$ number of cases (outliers were removed), $R^{2}$ adjusted $R^{2}, P$ significance level, $n . i$. indicates that the variable was not included in the model. Significant coefficients are marked with asterisks (* $P<0.05$; ** $P<0.01$; *** $P<0.001$ ) 
Table 5 Spearman's rank correlations between diagnostic and dominant species and selected habitat variables

\begin{tabular}{|c|c|c|c|c|c|c|c|c|}
\hline \multirow[t]{2}{*}{ Species } & \multirow{2}{*}{$\begin{array}{l}\text { Community } \\
\text { variant }\end{array}$} & \multirow[t]{2}{*}{ Frequency } & \multicolumn{6}{|c|}{ Spearman's coefficients } \\
\hline & & & DFF & $\mathrm{A} / \mathrm{AC}$ horizon thickness & $\mathrm{Ca}$ & $\mathrm{Cd}$ & $\mathrm{Pb}$ & $\mathrm{Zn}$ \\
\hline Brachypodium pinnatum & $C B$ & 22 & 0.19 & $0.45 *$ & -0.23 & $-0.53 *$ & $-0.47 *$ & $-0.55^{*}$ \\
\hline Helianthemum nummularium & $C B$ & 19 & 0.13 & $0.26^{*}$ & -0.19 & 0.09 & 0.20 & 0.04 \\
\hline Coronilla varia & $C B$ & 18 & -0.10 & 0.13 & $-0.31 *$ & -0.09 & -0.02 & -0.13 \\
\hline Anthyllis vulneraria & $C B$ & 17 & 0.18 & $-0.38 *$ & $0.36^{*}$ & 0.03 & 0.04 & 0.02 \\
\hline Centaurea scabiosa & $C B$ & 13 & 0.15 & -0.02 & 0.05 & $-0.39 *$ & $-0.35^{*}$ & $-0.35^{*}$ \\
\hline Knautia arvensis & $C B$ & 13 & 0.02 & 0.09 & -0.08 & -0.14 & -0.11 & -0.19 \\
\hline Polygala comosa & $C B$ & 11 & 0.14 & -0.06 & 0.19 & $-0.27 *$ & $-0.29 *$ & $-0.32 *$ \\
\hline Carlina acaulis & $C B$ & 9 & $0.26^{*}$ & 0.07 & 0.16 & $-0.25 *$ & $-0.32 *$ & -0.24 \\
\hline Carex caryophyllea & $C B F$ & 41 & 0.09 & -0.04 & 0.03 & $0.42 *$ & $0.40 *$ & $0.40^{*}$ \\
\hline Thymus pulegioides & $C B F$ & 35 & 0.12 & -0.23 & 0.19 & $0.36^{*}$ & $0.29 *$ & $0.36^{*}$ \\
\hline Scabiosa ochroleuca & $C B F$ & 34 & 0.17 & -0.02 & 0.17 & 0.11 & 0.05 & 0.07 \\
\hline Festuca ovina & $C B F$ & 33 & 0.13 & $-0.45^{*}$ & 0.21 & $0.58 *$ & $0.45^{*}$ & $0.60 *$ \\
\hline Dianthus carthusianorum & $C B F$ & 32 & 0.08 & -0.20 & -0.03 & $0.45 *$ & $0.31 *$ & $0.48 *$ \\
\hline Potentilla arenaria & $C B F$ & 30 & 0.10 & $-0.32 *$ & $0.34 *$ & $0.25 *$ & 0.14 & $0.25^{*}$ \\
\hline Festuca rubra & $C B R$ & 22 & -0.06 & 0.02 & -0.16 & -0.20 & -0.08 & -0.19 \\
\hline Rubus caesius & $C B R$ & 18 & $-0.32 *$ & 0.10 & -0.24 & $-0.42 *$ & $-0.27 *$ & $-0.39 *$ \\
\hline Galium album & - & 46 & -0.08 & -0.03 & -0.08 & $0.35 *$ & $0.33 *$ & $0.38 *$ \\
\hline Euphorbia cyparissias & - & 45 & 0.06 & -0.12 & 0.01 & -0.09 & -0.09 & -0.07 \\
\hline Lotus corniculatus & - & 33 & $0.45^{*}$ & -0.06 & 0.22 & 0.00 & -0.09 & 0.04 \\
\hline Pimpinella saxifraga & - & 31 & -0.02 & $-0.24 *$ & 0.13 & 0.22 & 0.17 & 0.17 \\
\hline Leontodon hispidus & - & 28 & 0.08 & $-0.32 *$ & $0.31 *$ & 0.20 & 0.05 & 0.24 \\
\hline Medicago falcata & - & 26 & 0.03 & 0.13 & -0.15 & $-0.34 *$ & $-0.36^{*}$ & $-0.29 *$ \\
\hline Achillea collina & - & 23 & 0.04 & 0.02 & -0.12 & -0.21 & -0.13 & -0.21 \\
\hline Plantago lanceolata & - & 23 & 0.05 & -0.15 & 0.07 & 0.11 & 0.07 & 0.13 \\
\hline Silene vulgaris & - & 23 & -0.02 & $-0.38 *$ & 0.22 & $0.59 *$ & $0.46^{*}$ & $0.59 *$ \\
\hline Carex hirta & - & 20 & -0.14 & -0.11 & 0.09 & $0.49 *$ & $0.38 *$ & $0.49 *$ \\
\hline Vicia cracca & - & 20 & -0.07 & 0.24 & -0.03 & 0.15 & 0.14 & 0.10 \\
\hline
\end{tabular}

The list of species includes those diagnostic of the typical variant of Carlino acaulis-Brometum erecti $(C B)$, the Festuca ovina variant (CBF) and the Rubus caesius variant (CBR), according to Chytrý (2007), and other frequent plants (recorded in at least $30 \%$ of sites). Significant coefficients $(P<0.05)$ are asterisked

$D F F$ distance from the forest

barely visible in terms of soil properties-the $C B R$ soil did not differ from other soils in the total $\mathrm{N}$ and $\mathrm{P}$ concentrations, organic $\mathrm{C}$ concentration or thickness of the $\mathrm{O}$ horizon; it only had elevated levels of available P. However, the emergence of nutrient-demanding and synanthropic plants (e.g. Rubus caesius and Solidago canadensis) suggests that the supply of nutrients is to be taken into account in explaining the species composition of the $C B R$ community.

The number of plant species is a parameter responsive to environmental changes (Tilman 1988; Grime 2001). However, in this study, it did not correlate (or correlated poorly) with the majority of the habitat characteristics (e.g. $\mathrm{pH}$ or clay content). The reason for this was likely limited variability of heap habitats. This did not apply to the concentrations of heavy metals, which varied largely among sites. In this case, lack of significant differences in species richness between $C B, C B F$ and $C B R$ grasslands and the relatively weak relationship between heavy metals and species richness can be explained by the interaction of metal toxicity and species composition. High heavy metal contamination eliminated some species, but at the same time, it promoted the growth of others due to reduction of interspecific competition; low heavy metal contamination was not harmful for plants, hence it allowed metal-sensitive competitors (e.g. Brachypodium pinnatum) to survive and dominate the community. A similar mechanism has been described for plant communities affected by natural disturbances such as grazing or soil perturbation by animals (Bobbink 1991; Barbaro et al. 2004; Questad and Foster 2007; Stevens et al. 2010; Kurek et al. 2014). 


\section{Conclusions}

Structure of the grassland community that colonizes sites of historical $\mathrm{Zn}-\mathrm{Pb}$ mining (heaps) is determined primarily by the amount of heavy metals in the soil. With increasing heavy metal stress, metal-sensitive plants withdraw. This loss of species is partly compensated by the emergence of metal-tolerant plants. As a result, typical dry grassland changes into heavy metal grassland, while the species richness remains relatively constant.

Metal-tolerant vegetation may develop under low- and high-contamination conditions. In the former case, it occupies heaps with shallow, skeletal soil. In contrast, metal-sensitive vegetation grows on heaps with well-developed soil. These observations suggest that heavy metal grasslands colonizing substrates with relatively low metal toxicity are ephemeral communities, and tend to succeed over time. The direction of this succession is affected by the surrounding vegetation. Under high-contamination conditions, this process seems to be greatly slowed down.

Acknowledgments We thank Małgorzata Stanek, Elżbieta Chrzanowska, Stanisław Braniewski and Urszula Korzeniak for their help with the laboratory work. We are grateful to Krystyna Grodzińska and the four anonymous referees for their valuable input on an earlier version of the manuscript. This study was financed by the National Science Centre, Poland (Grant No. N N305 018040). The W. Szafer Institute of Botany, Polish Academy of Sciences, also provided partial funding.

\section{Compliance with ethical standards}

Conflict of interest The authors declare that they have no conflict of interest.

Open Access This article is distributed under the terms of the Creative Commons Attribution 4.0 International License (http://crea tivecommons.org/licenses/by/4.0/), which permits unrestricted use, distribution, and reproduction in any medium, provided you give appropriate credit to the original author(s) and the source, provide a link to the Creative Commons license, and indicate if changes were made.

\section{References}

Baker AJM, Ernst WHO, van der Ent A, Ginocchio R (2010) Metallophytes: the unique biological resource, its ecology and conservational status in Europe, central Africa and Latin America. In: Batty LC, Hallberg KB (eds) Ecology of industrial pollution. Cambridge University Press, Cambridge, pp 7-40

Barbaro L, Dutoit T, Anthelmea F, Corcket E (2004) Respective influence of habitat conditions and management regimes on prealpine calcareous grasslands. J Environ Manag 72:261-275

Baumbach H (2012) Metallophytes and metallicolous vegetation: evolutionary aspects, taxonomic changes and conservational status in Central Europe. In: Tiefenbacher J (ed) Perspectives on nature conservation-patterns, pressures and prospects. InTech, Rijeka, pp 93-118
Becker T, Brändel M (2007) Vegetation-environment relationships in a heavy metal-dry grassland complex. Folia Geobot 42:11-28

Bobbink R (1991) Effects of nutrient enrichment in Dutch chalk grassland. J Appl Ecol 28:28-41

Braun-Blanquet J (1964) Pflanzensoziologie, Grundzüge der Vegetationskunde, 3rd edn. Springer, Wien

Brown G (1994) Soil factors affecting patchiness in community composition of heavy metal contaminated areas of Western Europe. Vegetation 115:77-90

Brown G (2001) The heavy-metal vegetation of north-western mainland Europe. Botanische Jahrbücher Für Systematik, Pflanzengeschichte Und Pflanzengeographie 123:63-110

Butaye J, Jacquemyn H, Honnay O, Hermy M (2002) The species pool applied to forests in a fragmented landscape: dispersal limitation versus habitat limitation. J Veg Sci 13:27-34

Cabała J, Zogala B, Dubiel R (2008) Geochemical and geophysical study of historical $\mathrm{Zn}-\mathrm{Pb}$ ore processing waste dump areas (Southern Poland). Pol J Environ Stud 17:693-700

Chytrý M (ed) (2007) Vegetation of the Czech Republic 1. Grassland and heathland vegetation. Academia, Praha

Chytrý M (ed) (2009) Vegetation of the Czech Republic 2. Ruderal, weed, rock and scree vegetation. Academia, Praha

Chytrý M (ed) (2013) Vegetation of the Czech Republic 4. Forest and scrub vegetation. Academia, Praha

Clark RK, Clark SC (1981) Floristic diversity in relation to soil characteristics in a lead mining complex in the Pennines, England. New Phytol 87:799-815

Cohn EV, Trueman IC, Tokarska-Guzik B, Rostański A, Woźniak G (2001) The flora and vegetation of an old solvay process tip in Jaworzno (Upper Silesia, Poland). Acta Soc Bot Pol 70:47-60

Dormann CF, McPherson JM, Araújo MB et al (2007) Methods to account for spatial autocorrelation in the analysis of species distributional data: a review. Ecography 30:609-628

Ernst WHO (1974) Schwermetallvegetation der Erde. G. Fischer Verlag, Stuttgart

Ernst WHO (2006) Evolution of metal tolerance in higher plants. For Snow Landsc Res 80:251-274

Grime JR (2001) Plant strategies, vegetation processes, and ecosystem properties. Wiley, Chichester

Grodzińska K, Szarek-Łukaszewska G (2009) Heavy metal vegetation in the Olkusz region (southern Poland)—preliminary studies. Pol Bot J 54:105-112

Kruckeberg AR, Kruckeberg AI (1989) Endemic metallophytes. Their taxonomic, genetic and evolutionary attributes. In: Shaw AJ (ed) Heavy metal tolerances in plants: evolutionary aspects. CRC Press, Boca Raton, pp 301-312

Kurek P, Kapusta P, Holeksa J (2014) Burrowing by badgers (Meles meles) and foxes (Vulpes vulpes) changes soil conditions and vegetation in a European temperate forest. Ecol Res 29:1-11

Lejeune K, Galbraith H, Lipton JA, Kapustka LA (1996) Effects of metals and arsenic on riparian communities in southwest Montana. Ecotoxicology 5:297-312

Lorenc H (ed) (2005) Atlas of the climate of Poland. The Institute of Meteorology and Water Management, Warszawa

Loydi A, Lohse K, Otte A, Donath TW, Eckstein RL (2013) Distribution and effects of tree leaf litter on vegetation composition and biomass in a forest grassland ecotone. JPE 7:264-275

Lucassen ECHET, van Kempen MML, Roelofs JGM, van der Velde G (2010) Decline in metallophytes in tertiary polluted floodplain grasslands in the Netherlands: experimental evidence for metal and nutritional changes in soil as driver factors. Chem Ecol 26:273-287

Mapaure I, Chimwamurombe PM, Mapani BS, Kamona FA (2011) Impacts of mine dump pollution on plant species diversity, 
composition and structure of a semiarid savanna in Namibia. Afr J Range Forage Sci 28:149-154

McDonnell MJ, Stiles EW (1983) The structural complexity of old field vegetation and the recruitment of bird-dispersed plant species. Oecologia 56:109-116

Mirek Z, Piękoś-Mirkowa H, Zając A, Zając M (2002) Flowering plants and pteridophytes of Poland. A checklist. Biodiversity of Poland 1. Publishing House W. Szafer Institute of Botany Polish Academy of Science, Kraków

Mocek A, Drzymała S, Maszner P (2004) Genesis, analysis and classification of soils. Agricultural University of Poznań, Poznań

Myking T, Aarrestad PA, Derome J, Bakkestuen V, Bjerke JW, Gytarsky ML, Isaeva L, Karaban R, Korotkov V, Lindgren M, Lindroos AJ, Røsberg I, Salemaa M, Tømmervik H, Vassilieva N (2009) Effects of air pollution from a nickel-copper industrial complex on boreal forest vegetation in the joint RussianNorwegian-Finnish border area. Boreal Environ Res 14:279-296

Myster RW, Pickett STA (1993) Effects of litter, distance, density and vegetation patch type on postdispersal tree seed predation in old fields. Oikos 66:381-388

Novák J, Konvička M (2006) Proximity of valuable habitats affects succession patterns in abandoned quarries. Ecol Eng 26:113-122

Novák J, Prach K (2003) Vegetation succession in basalt quarries: pattern on a landscape scale. Appl Veg Sci 6:111-116

Økland R (2007) Wise use of statistical tools in ecological field studies. Folia Geobot 42:123-140

Økland RH, Økland T, Rydgren K (2001) Vegetation-environment relationships of boreal spruce swamp forests in Østmarka Nature Reserve, SE Norway. Sommerfeltia 29:1-190

Olsson G (1987) Effects of dispersal mechanisms on the initial pattern of old-field succession. Acta Oecol 8:379-390

Pandey LK, Han T, Gaur JP (2015) Response of a phytoplanktonic assemblage to copper and zinc enrichment in microcosm. Ecotoxicology 24:573-582

Pen-Mouratov S, Nosir S, Yu J, Rakhmonkulova S, Kodirov O, Barness G, Kersten M, Steinberger Y (2014) Successive development of soil ecosystems at abandoned coal-ash landfills. Ecotoxicology 23:880-897

Podbielkowski Z (1995) Migrations of plants. WSiP, Warszawa

Prach K, Řehounková K (2006) Vegetation succession over broad geographical scales: which factors determine the patterns? Preslia 78:469-480

Prasad MNV, Hagemeyer J (eds) (1999) Heavy metal stress in plants-from molecules to ecosystems. Springer, Heidelberg

Proctor J (2003) Vegetation and soil and plant chemistry on ultramafic rocks in the tropical Far East. Perspect Plant Ecol Evol Syst 6:105-124

Punz W, Mucina L (1997) Vegetation on anthropogenic metalliferous soils in the Eastern Alps. Folia Geobot 32:283-295

Questad EJ, Foster BL (2007) Vole disturbances and plant diversity in a grassland metacommunity. Oecologia 153:341-351

Raunkiaer C (1934) The life forms of plants and statistical plant geography. Oxford University Press, Oxford
Řehounková K, Prach K (2010) Life-history traits and habitat preferences of colonizing plant species in long-term spontaneous succession in abandoned gravel-sand pits. Basic Appl Ecol $11: 45-53$

Rutkowski L (2008) A key to identification of vascular plants of lowland Poland. Wydawnictwo Naukowe PWN, Warszawa

Simon E (1978) Heavy metals in soils, vegetation development and heavy metal tolerance in plant populations from metalliferous areas. New Phytol 81:175-188

Stefanowicz AM, Woch MW, Kapusta P (2014) Inconspicuous waste heaps left by historical $\mathrm{Zn}-\mathrm{Pb}$ mining are hot spots of soil contamination. Geoderma 235-236:1-8

Stevens CJ, Ken Thompson J, Grime P, Long ChJ, Gowing DJG (2010) Contribution of acidification and eutrophication to declines in species richness of calcifuge grasslands along a gradient of atmospheric nitrogen deposition. Funct Ecol $24: 478-484$

Strandberg B, Axelsen JA, Pedersen MB, Jensen J, Attrill MJ (2006) Effect of a copper gradient on plant community structure. Environ Toxicol Chem 25:743-753

Suder A, Cabała S (2004) Vegetation of Trzebinia town in conditions of strong human impact, 1, vascular flora. Arch Environ Prot 30:77-104

Szarek-Łukaszewska G, Grodzińska K (2011) Grasslands of a Zn-Pb post-mining area (Olkusz Ore-bearning Region, S Poland). Pol Bot J 56:245-260

ter Braak CJF, Šmilauer P (2002) Canoco reference manual and CanoDraw for Windows user's guide: software for canonical community ordination (version 4.5). Microcomputer Power, Ithaca, New York

Tilman D (1988) Plant strategies and the dynamics and function of plant communities. Princeton University Press, Princeton

Tokarska-Guzik B (1999) Atlas of vascular plants distribution in Jaworzno town (Silesian. Upland). Prace Botaniczne Uniwersytetu Jagiellońskiego 34:1-292

Válega M, Lillebø AI, Pereira ME, Duarte AC, Pardal MA (2008) Long-term effects of mercury in a salt marsh: hysteresis in the distribution of vegetation following recovery from contamination. Chemosphere 71:765-772

Whiting SN, Reeves RD, Richards D, Johnson MS, Cooke JA, Malaisse F, Paton A, Smith JAC, Angle JS, Chaney RL, Ginocchio R, Jaffre T, Johns R, McIntyre T, Purvis OW, Salt DE, Schat H, Zhao FJ, Baker AJM (2004) Research priorities for conservation of metallophyte biodiversity and their potential for restoration and site remediation. Rest Ecol 12:106-116

Woch MW (2011) Xerothermic vegetation of fallow lands in western Małopolska. Ann UMCS C 66:105-120

Woch MW, Radwańska M, Stefanowicz AM (2013) Flora of spoil heaps after hard coal mining in Trzebinia (southern Poland): effect of substratum properties. Acta Bot Croat 72:56-75 